\title{
Human Rights and Crimes against Humanity
}

\section{Eric D. Weitz, Series Editor}

For a full list of titles in the series, go to https://press.princeton.edu/catalogs/ series/title/human-rights-and-crimes-against-humanity.html.

Sharing Responsibility: The History and Future of Protection from Atrocities, Luke Glanville

A World Divided: The Global Struggle for Human Rights in the Age of Nation-States, Eric D. Weitz

The Crime of Aggression: The Quest for Justice in an Age of Drones, Cyberattacks, Insurgents, and Autocrats, Noah Weisbord

The Killing Season: A History of the Indonesian Massacres, 1965-66, Geoffrey B. Robinson

Evidence for Hope: Making Human Rights Work in the 21st Century, Kathryn Sikkink

"They Can Live in the Desert but Nowhere Else": A History of the Armenian Genocide, Ronald Grigor Suny

Child Migration and Human Rights in a Global Age, Jacqueline Bhabha The Young Turks' Crime against Humanity: The Armenian Genocide and Ethnic Cleansing in the Ottoman Empire, Taner Akçam

The International Human Rights Movement: A History, Aryeh Neier

All the Missing Souls: A Personal History of the War Crimes Tribunals, David Scheffer Against Massacre: Humanitarian Interventions in the Ottoman Empire, 1815-1914,

Davide Rodogno

Stalin's Genocides, Norman M. Naimark

"If You Leave Us Here, We Will Die": How Genocide Was Stopped in East Timor, Geoffrey B. Robinson

Terror in Chechnya: Russia and the Tragedy of Civilians in War, Emma Gilligan Torture and the Twilight of Empire: From Algiers to Baghdad, Marnia Lazreg 


\section{Sharing Responsibility}

The History and

Future of Protection

from Atrocities

Luke Glanville 


\section{Copyright (C) 2021 by Princeton University Press}

Princeton University Press is committed to the protection of copyright and the intellectual property our authors entrust to us. Copyright promotes the progress and integrity of knowledge. Thank you for supporting free speech and the global exchange of ideas by purchasing an authorized edition of this book. If you wish to reproduce or distribute any part of it in any form, please obtain permission.

Requests for permission to reproduce material from this work should be sent to permissions@press.princeton.edu

Published by Princeton University Press

41 William Street, Princeton, New Jersey 08540

6 Oxford Street, Woodstock, Oxfordshire OX20 ITR

press.princeton.edu

All Rights Reserved

ISBN 978-0-691-20502-1

ISBN (e-book) 978-0-691-20501-4

British Library Cataloging-in-Publication Data is available

Editorial: Eric Crahan, Priya Nelson and Thalia Leaf

Production Editorial: Jenny Wolkowicki

Jacket design: Layla Mac Rory

Production: Danielle Amatucci

Publicity: Kate Hensley and Amy Stewart

Copyeditor: Joseph Dahm

This book has been composed in Adobe Text and Gotham

Printed on acid-free paper. $\infty$

Printed in the United States of America

10988765543321 
For Clare 
